\title{
Fluid-metapelite interaction in an ultramafic mélange: implications for mass transfer along the slab-mantle interface in subduction zones
}

\author{
Yasushi Mori $^{1 *}$, Miki Shigeno $^{1}$ and Tadao Nishiyama ${ }^{2}$
}

\begin{abstract}
The slab-mantle interface in subduction zones is a site of tectonic mixing of crustal and mantle rocks. It is the interface for fluid flow of slab-derived components into the mantle wedge. To assess the fluid-rock interaction along the slab-mantle interface, we studied the bleaching of pelitic schist in an ultramafic mélange. The Nishisonogi metamorphic rocks in Kyushu, Japan, comprise ultramafic mélanges intercalated with epidote-blueschist facies schists. The ultramafic mélange consists of tectonic blocks of various lithologies and a matrix of chlorite-actinolite schist and serpentinite. Along the contact with the mélange matrix, pelitic schist blocks are bleached mainly due to the modal increase of albite and the consumption of carbonaceous material. The bleaching is probably attributed to infiltration of Na-rich external fluid from the mélange matrix. Mass balance analysis indicates losses of $C, R b, K_{2} O$, $\mathrm{Ba}, \mathrm{Pb}$, and $\mathrm{SiO}_{2}$ from the bleached pelitic schist, although $\mathrm{Al}_{2} \mathrm{O}_{3}, \mathrm{TiO}_{2}, \mathrm{Sc}, \mathrm{Y}, \mathrm{Zr}, \mathrm{Nb}, \mathrm{La}, \mathrm{Ce}$, and $\mathrm{Nd}$ remain immobile. This suggests fractionation of large-ion lithophile elements (LILE) and Pb from the high-field-strength elements and rare earth elements during the bleaching. If this ultramafic mélange is analogous to the slab-mantle interface, similar infiltration metasomatism will promote liberation of C, Si, LILE, and $\mathrm{Pb}$ from subducting metapelites and enhance metasomatism of the mantle wedge.
\end{abstract}

Keywords: Element fractionation; Fluid-rock interaction; Metapelite; Subduction zone mélange; Nishisonogi metamorphic rocks

\section{Findings Introduction}

Fluid flow is an agent of large-scale mass transfer in subduction zones and plays a key role in mantle metasomatism and arc magmatism (Peacock 1990; Bebout 1996, 2007a, 2007b, 2013; Manning 2004; Klemd 2013; Spandler and Pirard 2013). At great depths in subduction zones (15 to $100 \mathrm{~km}$ ), fluids (aqueous fluids in shallower levels and possibly silicate melts in deeper levels; $c f$. Bebout 2007a, b) derived from subducting slabs can transport various components into the mantle wedge, causing hydration and metasomatism of the mantle (Maury et al. 1992; Ryan et al. 1996; Morris and Ryan 2003; Schmidt and Poli 2003; Rüpke et al. 2004). It is generally believed that such fluid flow is essential to generate arc magmas with elevated

\footnotetext{
* Correspondence: mori@kmnh.jp

${ }^{1}$ Kitakyushu Museum of Natural History and Human History, 2-4-1 Higashida, Yahatahigashi-ku, Kitakyushu 805-0071, Japan

Full list of author information is available at the end of the article
}

concentrations of fluid-mobile components such as largeion lithophile elements (LILE; e.g., Ba, K, Rb, Cs), B, U, and $\mathrm{Pb}$ (Morris et al. 1990; Hawkesworth et al. 1993; Tatsumi and Eggins 1995; Davidson 1996; Elliott 2003).

Recent studies of subduction zone mélanges have revealed that significant fluid flow and fluid-rock interaction took place along the slab-mantle interface (Bebout and Barton 1989, 1993, 2002; Sorensen and Grossman 1989, 1993; King et al. 2003, 2006, 2007; Breeding et al. 2004; Marschall et al. 2006; Spandler et al. 2008; Miller et al. 2009; Penniston-Dorland et al. 2010, 2012). The mélanges represent tectonic and metasomatic mixing of sedimentary, mafic, and ultramafic rocks along the interface region at the contact between the subducting slab and the mantle wedge. The mixing may involve devolatilization reactions that would not occur during simple (essentially closedsystem) metamorphism of each lithology. Moreover, fluidrock interactions or exchanges between the sedimentary and ultramafic rocks will produce new hybrid rocks. The 
hybrid rocks have the potential to take up and release components distinct from the protoliths. Thus, fluid-rock interaction in mélanges probably affects the mass transfer of slab-derived components into the wedge mantle.

This paper describes an example of fluid-metapelite interaction in a subduction zone mélange intercalated with epidote-blueschist facies schists. Metapelites are the most important reservoirs of LILE in subducting slabs. Mass balance analysis provides evidence of the liberation of $\mathrm{C}, \mathrm{Si}$, LILE, and $\mathrm{Pb}$ from metapelites during infiltration metasomatism.

\section{Geological background}

The Nishisonogi metamorphic rocks in Kyushu, Japan, represent a Late Cretaceous subduction complex that consists of epidote-blueschist facies schists with minor serpentinite (Figure 1). The schists include mainly pelitic, psammitic, and mafic lithologies. Phengitic muscovite in the pelitic and psammitic schists yields $\mathrm{K}-\mathrm{Ar}$ and ${ }^{40} \mathrm{Ar} /{ }^{39} \mathrm{Ar}$ plateau ages of 85 to $60 \mathrm{Ma}$ (Hattori and Shibata 1982; Faure et al. 1988). The matrix mineral assemblages of the pelitic and psammitic schists are carbonaceous material + garnet + chlorite + muscovite + albite + quartz \pm epidote and albite + muscovite + quartz \pm chlorite, respectively. The psammitic schist locally contains glaucophane + epidote/piemontite + hematite + rutile \pm garnet in the matrix. The mafic schist occurs as conformable layers $(<100 \mathrm{~m}$ in thickness) within the pelitic and psammitic schists. The matrix mineral assemblages of the mafic schist are actinolite/barroisite + epidote + chlorite + albite \pm quartz and glaucophane + epidote + chlorite + albite + hematite \pm quartz, with the former assemblage being dominant. The serpentinite, which is in tectonic contact with the schists, occurs as pod-like bodies $(<150 \mathrm{~m}$ in diameter $)$ and ultramafic mélanges
( $<350 \mathrm{~m}$ in thickness). The serpentinite pods typically have metasomatic rinds (Uchida and Muta 1957, 1958; Mori et al. 2007). The matrix mineral assemblage of the serpentinite is antigorite + magnetite \pm dolomite \pm magnesite \pm talc; chrysotile and lizardite are rare. The ultramafic mélanges contain tectonic blocks of metagabbro, mafic schist, pelitic schist, and albitite in a matrix of chlorite-actinolite schist, talc schist, and schistose serpentinite (Nishiyama 1989, 1990). Small blocks ( $<5 \mathrm{~m}$ in diameter) of jadeitite, omphacitite, rodingite, and zoisitite are found locally (Nishiyama 1978; Shigeno et al. 2005, 2012a, b; Mori et al. 2011).

One of the largest ultramafic mélanges in the study area is exposed at Nishikashiyama district in Nagasaki, Japan (Figure 1). A wide variety of rocks such as epidotebarroisite schist, epidote-glaucophane schist, pelitic schist, and albitite appear as discrete tabular blocks less than $10 \mathrm{~m}$ in thickness (Figure 2a). These blocks are mutually isolated by a mélange matrix ( $<5 \mathrm{~m}$ in thickness) of chlorite-actinolite schist. The mélange matrix locally contains thin lenses ( $<2 \mathrm{~m}$ in thickness) of serpentinite. In this mélange, all pelitic schist blocks show bleaching along the contact with the mélange matrix (Figure $2 \mathrm{~b}, \mathrm{c}$ ). The pelitic schist is normally black but becomes white when within several centimeters of the mélange matrix. The boundary between the unaltered part and bleached part of the pelitic schist is parallel to the contact.

\section{Sampling and analytical methods}

To study the bleaching of pelitic schist blocks, samples were collected from two outcrops in Nishikashiyama (Figure 2b, c). From each outcrop, one sample of bleached pelitic schist (BPS), three samples of neighboring unaltered pelitic schist (UPS), and one sample of chloriteactinolite schist (CAS) were taken. The BPS and UPS

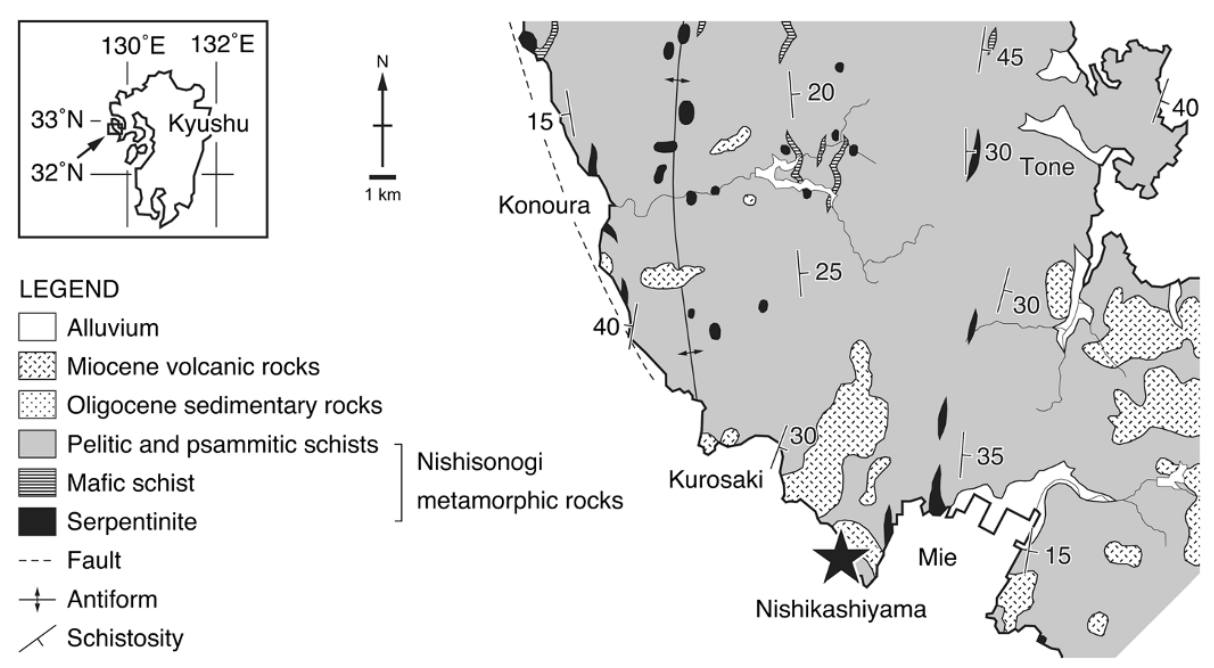

Figure 1 Geologic map of the southern part of Nishisonogi Peninsula, Kyushu, Japan. Star indicates sampling locality. 

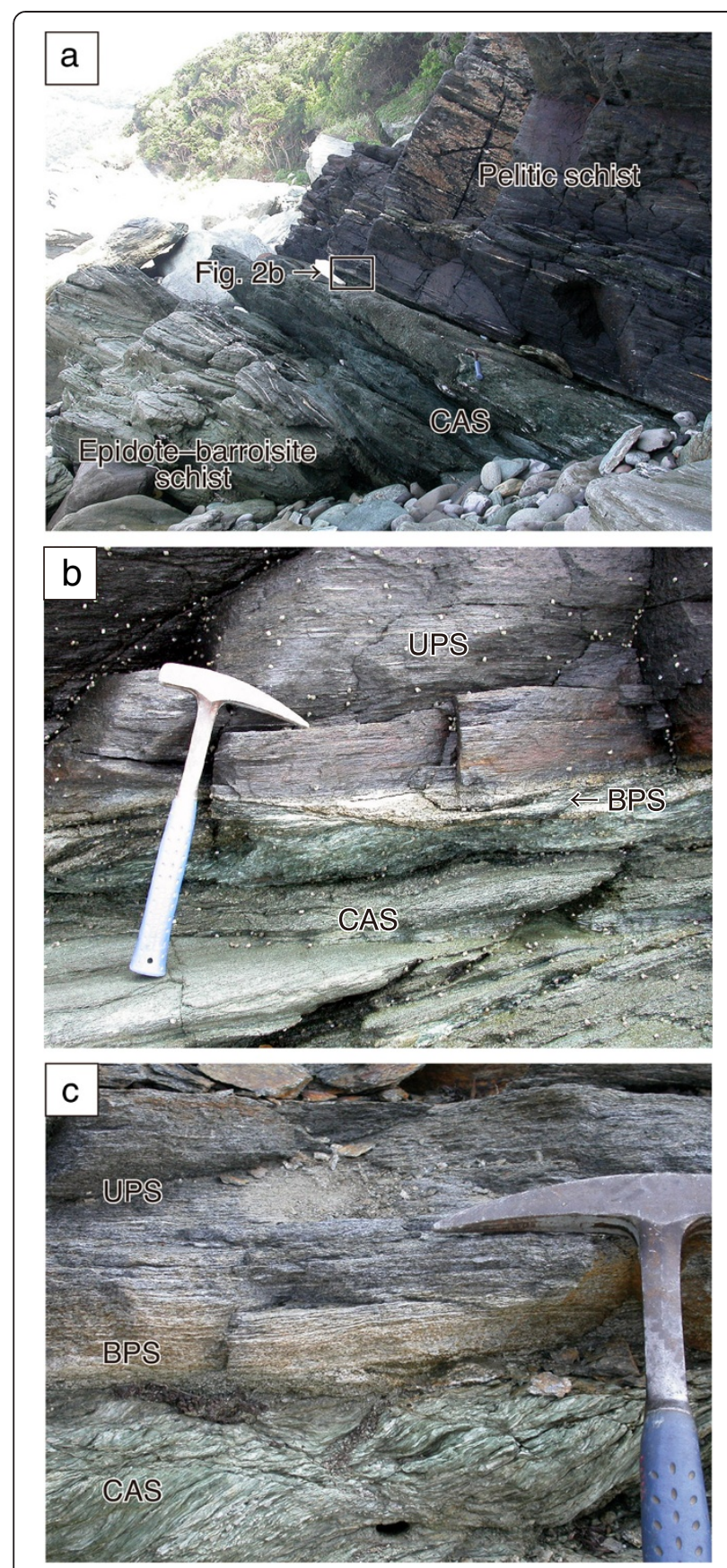

Figure 2 Photographs of the Nishikashiyama mélange. (a) Tectonic blocks of epidote-barroisite schist and pelitic schist in a mélange matrix of chlorite-actinolite schist, outcrop 1. (b, c) Bleaching of pelitic schist in outcrops 1 and 2, respectively. BPS, bleached pelitic schist; CAS, chlorite-actinolite schist; UPS, unaltered pelitic schist.

represent different stratigraphic layers of pelitic schist; sampling along a single layer was not possible.

The minerals in the samples were examined with a polarizing microscope under transmitted and reflected light. The modal compositions were measured by counting 2,000 points with a grid interval of $0.1 \mathrm{~mm}$ for each sample. Fluid inclusions and opaque minerals were analyzed with a Horiba Jobin Yvon LabRAM HR800 Raman spectrometer (HORIBA Jobin Yvon Inc., Edison, NJ, USA) equipped with a 514-nm argon ion laser housed at Kumamoto University, Japan.

The whole-rock compositions of the samples were determined with a PANalytical MagiX Pro X-ray fluorescence (XRF) spectrometer (PANalytical B.V., Almelo, The Netherlands) and a PerkinElmer 2400 II CHN element analyzer (PerkinElmer, Waltham, MA, USA) housed at the Kitakyushu Museum of Natural History and Human History, Japan. About $300 \mathrm{~g}$ of each sample was powdered and homogenized. About $4 \mathrm{~g}$ of the sample powder was heated to $950^{\circ} \mathrm{C}$ for $3 \mathrm{~h}$ to measure loss on ignition (LOI). Then, $1 \mathrm{~g}$ of the heated powder was prepared as a 1:5 dilution glass bead for XRF. The details of the XRF analysis followed the method of Mori and Mashima (2005). About $0.2 \mathrm{~g}$ of the unheated powder was used for $\mathrm{CHN}\left(\mathrm{H}_{2} \mathrm{O}\right.$ and $\mathrm{C}$ ) analysis. Finally, the XRF, LOI, and CHN data were combined as whole-rock compositions.

\section{Petrography}

Photomicrographs of the samples are shown in Figure 3. Modal compositions are shown in Figure 4.

\section{Unaltered pelitic schist}

The mineral assemblage of UPS is carbonaceous material + chlorite + muscovite + albite + quartz + titanite \pm garnet \pm calcite \pm epidote (Figure $3 \mathrm{a}$ ). Ore minerals are rare. A minor amount of accessory tourmaline is present in some samples. Carbonaceous material is 5 to 9 vol\% in the mode and occurs either as a matrix mineral or as inclusions in albite. It contains graphite and disordered carbons and is considered metamorphosed organic matter. Albite ( 15 to $37 \mathrm{vol} \%$ ) typically occurs as porphyroblasts of 1 to $2 \mathrm{~mm}$ in diameter. Chlorite (7 to $15 \mathrm{vol} \%$ ) and muscovite (14 to $33 \mathrm{vol} \%$ ) define the schistosity of the UPS. Quartz is 19 to 38 vol\% in the mode. Titanite is present in all the UPS samples.

\section{Bleached pelitic schist}

The mineral assemblage of the BPS is chlorite + muscovite + albite + quartz + titanite \pm epidote (Figure $3 b)$. This is essentially the same as the mineral assemblage of the UPS except for the notable absence of carbonaceous material. The BPS lacks carbonaceous material not only in the matrix but also in the albite porphyroblasts. The modal compositions indicate that the BPS is richer in albite (43 and 69 vol\% in outcrops 1 and 2, respectively) and is generally poorer in muscovite (18 and 4 vol\%) and quartz ( 29 and 8 vol\%) than the UPS. Titanite is present in all the BPS samples.

The albite porphyroblasts have numerous fluid inclusions along clusters of healed microcracks (Figure 3c). This 


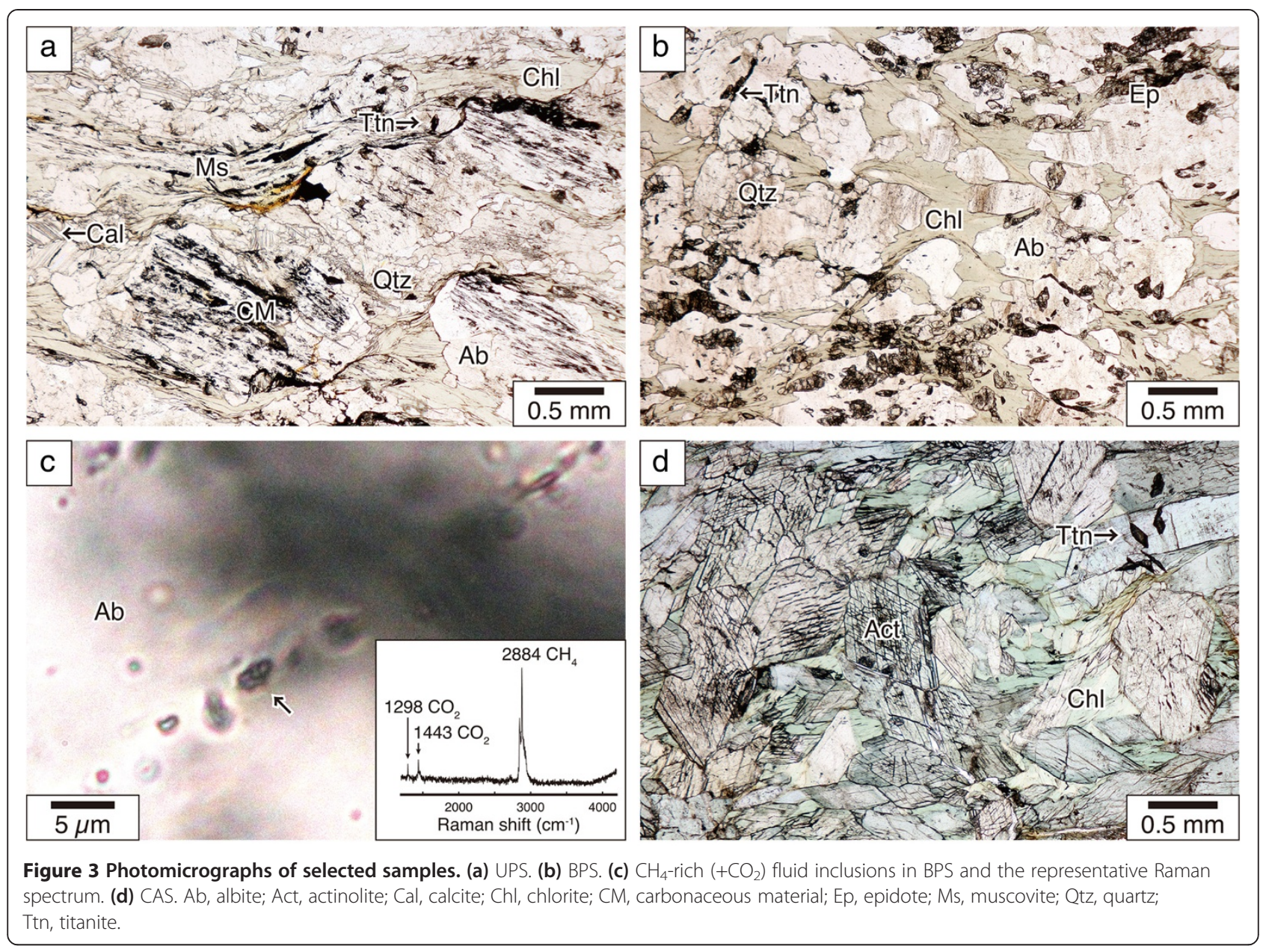

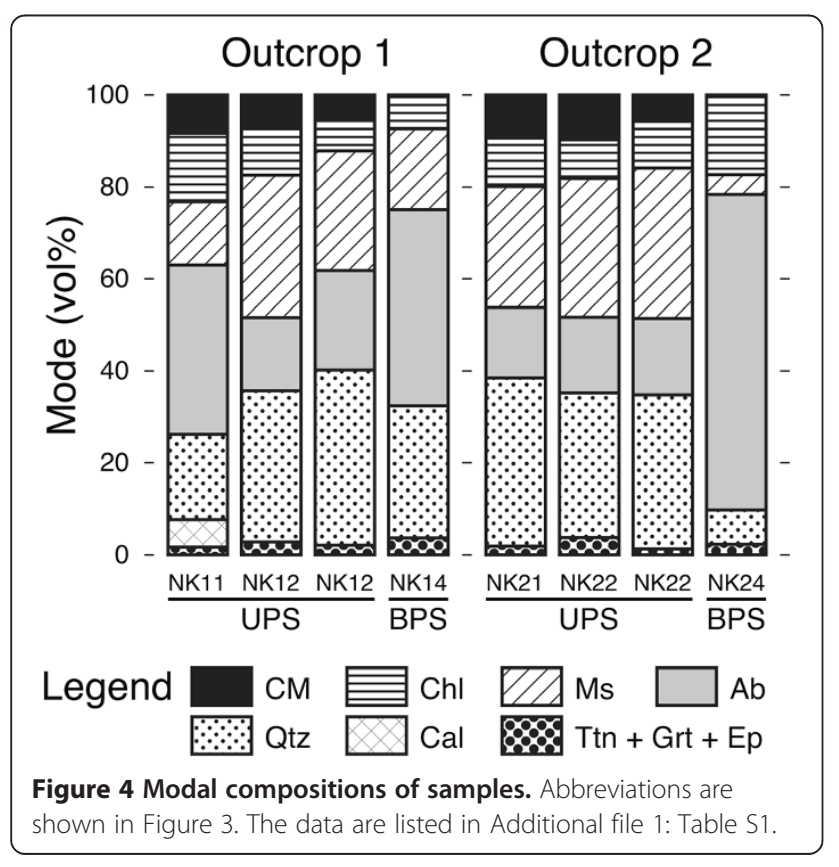

is a feature not found in UPS. The fluid inclusions are typically less than $5 \mu \mathrm{m}$ in size, have round shapes, and are filled by one phase $\left(\mathrm{H}_{2} \mathrm{O}\right.$ liquid) or two phases (liquid and a small gas bubble) at room temperature. There are two types of the two-phase inclusions: $\mathrm{CH}_{4}$-rich $\left( \pm \mathrm{CO}_{2}\right)$ inclusions and $\mathrm{H}_{2} \mathrm{O}$ inclusions. There is no obvious difference in the mode of occurrence of these two types.

\section{Chlorite-actinolite schist}

The mineral assemblage of the CAS is actinolite + chlorite + titanite + albite \pm tourmaline (Figure $3 \mathrm{~d}$ ). The actinolite is dominant in the mode ( 85 and 93 vol\% in outcrops 1 and 2, respectively), defines the schistosity, and occurs as euhedral grains of 0.1 to $5 \mathrm{~cm}$ long. Chlorite, titanite, and albite occur in the interstices among the actinolite grains.

\section{Whole-rock chemistry}

The whole-rock compositions of the samples are listed in Additional file 1: Table S1. As shown in Figure 4, carbonaceous material is the major reservoir of carbon. The sample NK11 contains both carbonaceous material and calcite (Figure 4), but division between $\mathrm{C}$ and $\mathrm{CO}_{2}$ is 
difficult. Thus, carbon in all the samples is regarded as $\mathrm{C}$ in the mass balance analysis discussed below.

\section{Discussion}

\section{Bleaching process of pelitic schist}

The bleaching of the pelitic schist involves the changes in mineralogy and whole-rock chemistry. There are two possible mechanisms. As the UPS is a boundary layer, it may represent diffusive exchange of components between the pelitic schist and ultramafic mélange matrix. Boundary flow of external fluids may cause infiltration metasomatism of the pelitic schist.

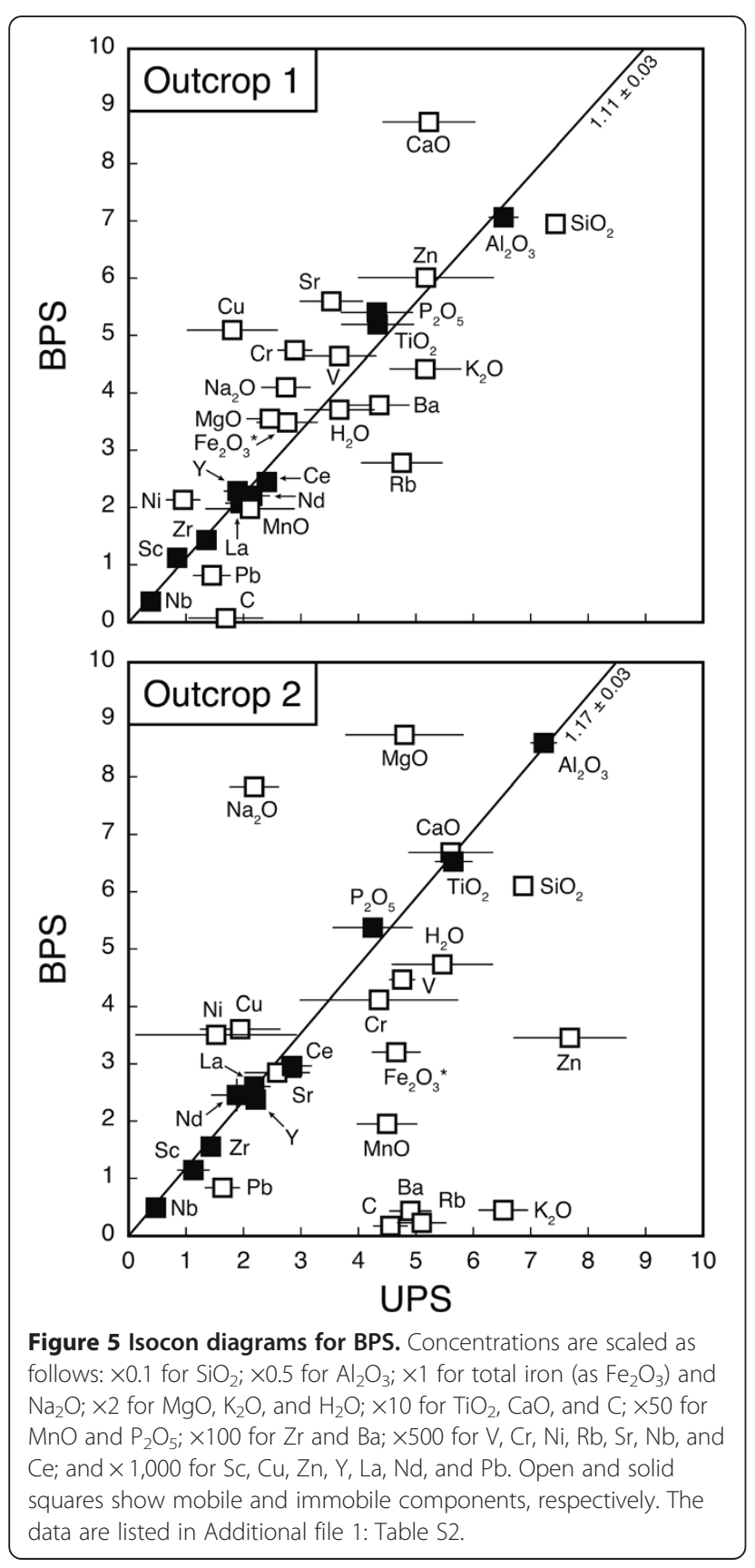

To examine the bleaching mechanisms, the chemical mass balance between the UPS and BPS was estimated using the isocon method (Grant 1986). As shown in Figure 2, the UPS gradually changes into the BPS upon approaching the margin of the pelitic schist block. There are no structural discontinuities between them, in contrast to the contact between the BPS and CAS. Thus, the UPS is considered the protolith of the BPS. In each outcrop, the average composition of the UPS was used as the unaltered reference frame. We regarded the standard deviation of the UPS compositions as the inherent heterogeneity of the protolith and used it to calculate the uncertainties of the mass balance analysis (Baumgartner and Olsen 1995).

The isocon diagrams for the BPS are shown in Figure 5. The isocon is defined by $\mathrm{TiO}_{2}, \mathrm{Al}_{2} \mathrm{O}_{3}, \mathrm{P}_{2} \mathrm{O}_{5}, \mathrm{Sc}, \mathrm{Y}, \mathrm{Zr}$, $\mathrm{Nb}, \mathrm{La}, \mathrm{Ce}$, and $\mathrm{Nd}$. These components are thought to be immobile in this metasomatic system. In outcrop 1 , the isocon slope $(=1.11 \pm 0.03)$ indicates that the UPS had lost $10 \%$ of its bulk mass during the bleaching. The elemental mass changes include losses of $15 \% \mathrm{SiO}_{2}, 23 \%$ $\mathrm{K}_{2} \mathrm{O}, 95 \% \mathrm{C}, 47 \% \mathrm{Rb}, 21 \% \mathrm{Ba}$, and $47 \% \mathrm{~Pb}$, along with gains of $33 \% \mathrm{MgO}, 34 \% \mathrm{Na}_{2} \mathrm{O}, 109 \% \mathrm{Ni}$, and $161 \% \mathrm{Cu}$, relative to the protolith values. The isocon diagram for outcrop 2 shows more dispersive distribution of data than that for outcrop 1, suggesting more intense metasomatism. In

Table 1 Element mass changes in BPS

\begin{tabular}{|c|c|c|c|c|}
\hline & \multicolumn{4}{|c|}{ Outcrop } \\
\hline & \multicolumn{2}{|l|}{1} & \multicolumn{2}{|l|}{2} \\
\hline & \multicolumn{2}{|c|}{ Sample NK14 } & \multicolumn{2}{|c|}{ Sample NK24 } \\
\hline & $\begin{array}{l}(\mathrm{g} / 100 \mathrm{~g} \text { of } \\
\text { protolith) }\end{array}$ & (\% change) & $\begin{array}{l}\text { (g/100 g of } \\
\text { protolith) }\end{array}$ & (\% change) \\
\hline $\mathrm{SiO}_{2}$ & $-11 \pm 2$ & -15 & $-16 \pm 2$ & -23 \\
\hline $\mathrm{Fe}_{2} \mathrm{O}_{3}^{\mathrm{a}}$ & $+0.4 \pm 0.5$ & +14.9 & $-1.9 \pm 0.4$ & -40.0 \\
\hline $\mathrm{MnO}$ & $-0.00 \pm 0.02$ & -11.87 & $-0.06 \pm 0.01$ & -62.60 \\
\hline $\mathrm{MgO}$ & $+0.4 \pm 0.2$ & +32.9 & $+1.4 \pm 0.5$ & +56.6 \\
\hline $\mathrm{CaO}$ & $+0.27 \pm 0.08$ & +51.44 & $+0.01 \pm 0.07$ & +2.25 \\
\hline $\mathrm{Na}_{2} \mathrm{O}$ & $+0.1 \pm 0.4$ & +34.4 & $+4.5 \pm 0.4$ & +203.7 \\
\hline $\mathrm{K}_{2} \mathrm{O}$ & $-0.6 \pm 0.3$ & -23.2 & $-3.1 \pm 0.2$ & -93.4 \\
\hline $\mathrm{H}_{2} \mathrm{O}$ & $-0.16 \pm 0.31$ & 18.75 & $-0.7 \pm 0.5$ & -25.1 \\
\hline \multirow[t]{2}{*}{ C } & $-0.16 \pm 0.07$ & -94.78 & $-0.44 \pm 0.03$ & -95.70 \\
\hline & ( $\mu \mathrm{g} / \mathrm{g}$ of protolith) & (\% change) & ( $\mu \mathrm{g} / \mathrm{g}$ of protolith) & (\% change) \\
\hline V & $+11 \pm 13$ & +15 & $-19 \pm 6$ & -19 \\
\hline $\mathrm{Cr}$ & $+28 \pm 6$ & +48 & $-15 \pm 28$ & -18 \\
\hline $\mathrm{Ni}$ & $+21 \pm 6$ & +109 & $+30 \pm 28$ & +96 \\
\hline $\mathrm{Cu}$ & $+29 \pm 8$ & +161 & $+12 \pm 7$ & +59 \\
\hline $\mathrm{Zn}$ & $+2 \pm 12$ & +5 & $-47 \pm 10$ & -61 \\
\hline $\mathrm{Rb}$ & $-45 \pm 14$ & -47 & $-98 \pm 9$ & -95 \\
\hline $\mathrm{Sr}$ & $+32 \pm 11$ & +46 & $-2 \pm 12$ & -4 \\
\hline $\mathrm{Ba}$ & $-92 \pm 52$ & -21 & $-453 \pm 36$ & -91 \\
\hline $\mathrm{Pb}$ & $-7 \pm 3$ & -7 & $-9 \pm 3$ & -55 \\
\hline
\end{tabular}

${ }^{\mathrm{a}}$ Total iron as $\mathrm{Fe}_{2} \mathrm{O}_{3}$. 
outcrop 2 , the isocon slope $(=1.17 \pm 0.03)$ indicates that the UPS lost $14 \%$ of its bulk mass during the bleaching. The elemental mass changes include losses of $23 \% \mathrm{SiO}_{2}, 93 \%$ $\mathrm{K}_{2} \mathrm{O}, 96 \% \mathrm{C}, 95 \% \mathrm{Rb}, 91 \% \mathrm{Ba}$, and $55 \% \mathrm{~Pb}$, along with gains of $57 \% \mathrm{MgO}, 204 \% \mathrm{Na}_{2} \mathrm{O}, 96 \% \mathrm{Ni}$, and $59 \% \mathrm{Cu}$, relative to the protolith values.

The chemical mass balance suggests that the bleaching of the pelitic schist is an open system with respect to some mobile components. For example, the significant gain of $\mathrm{Na}_{2} \mathrm{O}$ (Table 1 ) is probably unable to explain by simple exchange between the pelitic schist and ultramafic mélange matrix. As the $\mathrm{Na}_{2} \mathrm{O}$ concentration is typically low in the ultramafic mélange matrix, influx of Na-rich fluid would be necessary. Although the diffusive exchange of components is possible, the fluid flow and infiltration metasomatism are considered more important mechanisms of the bleaching.

\section{Element mobility and mineral stability}

The elemental mass changes (Table 1) are coupled to the stability of the key host minerals in the BPS (Figure 4). The loss of $\mathrm{SiO}_{2}$ and $\mathrm{C}$ corresponds to the decrease of quartz and the consumption of carbonaceous material, respectively. The loss of $\mathrm{K}_{2} \mathrm{O}, \mathrm{Rb}$, and $\mathrm{Ba}$ is correlated with the decrease of muscovite. The gain of $\mathrm{Na}_{2} \mathrm{O}$ and $\mathrm{MgO}$ reflects the increase of albite and chlorite, respectively. In outcrop 1, the gain of $\mathrm{CaO}$ and $\mathrm{Sr}$ is comparable with the increase of epidote [see Additional file 1: Table S1]. Some immobile components such as $\mathrm{TiO}_{2}, \mathrm{Y}, \mathrm{Nb}, \mathrm{La}$, $\mathrm{Ce}$, and $\mathrm{Nd}$ are probably held in titanite that remains stable. The mass change of total iron is inconsistent with the modal change. This may be because total iron contains ferric (mainly in epidote and chlorite) and ferrous oxides (mainly in chlorite).

A salient change during the bleaching of the pelitic schist is the consumption of carbonaceous material (Figures 3 and 4). As the BPS and CAS have the low $\mathrm{C}$ concentration and do not contain carbonate minerals, we infer that the infiltration of fluid from the mélange matrix converted the carbonaceous material to carbonic fluids. If the infiltrating fluid is reducing relative to the pore fluid in the pelitic schist, the carbonaceous material will be converted to hydrocarbons $\left(\mathrm{CH}_{4}\right.$, etc.). Alternatively, if the infiltrating fluid is oxidizing, the carbonaceous material will be converted to $\mathrm{CO}_{2}$. The $\mathrm{CH}_{4}$-rich $\left( \pm \mathrm{CO}_{2}\right)$ fluid inclusions in the BPS may be the traces of such processes (Figure 3c). Unfortunately, there are few records of the redox state of the fluids in the samples. Nishiyama (1990) described $\mathrm{CO}_{2}$ metasomatism of an exposed metabasite block in the Mie mélange $2.5 \mathrm{~km}$ northeast of Nishikashiyama (Figure 1). He speculated that the origin of the $\mathrm{CO}_{2}$-rich fluid $\left(X_{\mathrm{CO}_{2}}>0.785\right)$ was the oxidation of carbonaceous material in pelitic schist blocks. However, such a process may not be a suitable explanation for the case of the Nishikashiyama mélange because the BPS and CAS contain titanite and actinolite (Figure 3b, d). These minerals are destabilized under high- $X_{\mathrm{CO}_{2}}$ conditions (cf. Nishiyama 1990).

\section{Implications for mass transfer along the slab-mantle interface}

The most striking result of the mass balance analysis is the obvious correlation between the elemental mass changes and the ion radius and charge number. As shown in Figure $6 \mathrm{a}$, a significant mass of $\operatorname{LILE}(\mathrm{Rb}, \mathrm{K}, \mathrm{Ba})$ and $\mathrm{Pb}$

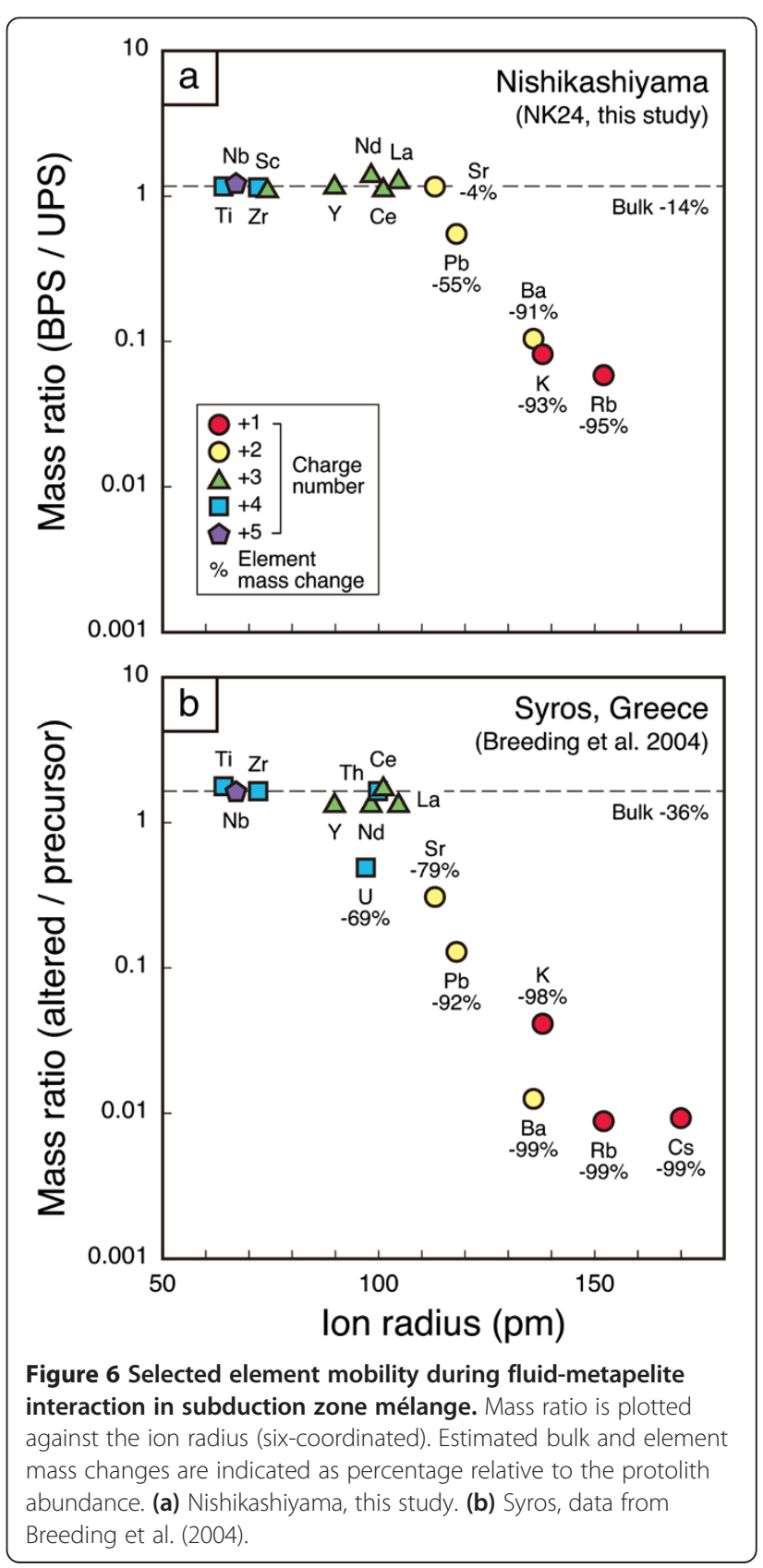


with relatively large ion radii and low charge numbers is lost in the BPS. In contrast, the high-field-strength elements (HFSE; e.g., $\mathrm{Ti}, \mathrm{Nb}$, and $\mathrm{Zr}$ ) and rare earth elements (REE; e.g., La, Ce, and $\mathrm{Nd}$ ) remain immobile. Consequently, the infiltration metasomatism causes fractionation of LILE and $\mathrm{Pb}$ from the HFSE and REE along with the bleaching of the pelitic schist. Because the CAS has low concentrations of LILE and $\mathrm{Pb}$ [see Additional file 1: Table S2], these components are probably liberated from the pelitic schist blocks and migrate away via the fluid flow.

Breeding et al. (2004) reported similar fluid-metapelite interaction from an eclogite facies mélange exposed in Syros, Greece. Near the meta-ultramafic mélange matrix, the mineral assemblage of the metapelite was altered from phengite + sodic pyroxene + epidote + garnet + glaucophane + quartz + titanite + rutile + zircon to glaucophane + chlorite + albite + magnetite + apatite + titanite + rutile + zircon (Figure 6b). The difference between the mineralogical changes in Syros and Nishikashiyama probably reflects the difference in the $P-T$ conditions of the fluid-metapelite interaction. Nevertheless, the elemental mass changes are similar (Figure 6). LILE, $\mathrm{Pb}, \mathrm{Sr}$, and $\mathrm{U}$ are significantly lost during the alteration, but the HFSE, REE, and Th remain nearly immobile. Such a fluid-metapelite interaction and element fractionation may occur at various depths (eclogite facies and epidote-blueschist facies to lower $P$ - $T$ conditions) along the slab-mantle interface in subduction zones.

\section{Conclusions}

This paper describes bleaching of pelitic schist blocks in an ultramafic mélange intercalated with epidote-blueschist facies schists of the Nishisonogi metamorphic rocks. The bleaching is attributed to infiltration of Na-rich external fluid and involves liberation of $\mathrm{C}$ (as carbonic fluids), $\mathrm{Si}$, $\mathrm{Rb}, \mathrm{K}, \mathrm{Ba}$, and $\mathrm{Pb}$ from the pelitic schist. Titanium, $\mathrm{Nb}$, $\mathrm{Zr}, \mathrm{La}, \mathrm{Ce}$, and $\mathrm{Nd}$ remain immobile, so the LILE and $\mathrm{Pb}$ are fractionated from the HFSE and REE. Such a fluidmetapelite interaction may occur at various depths along the slab-mantle interface that is the site of tectonic mixing of sedimentary, mafic, and ultramafic rocks. Therefore, ultramafic mélanges are a potential source of slab-derived components and play an important role in material recycling in subduction zones.

\section{Additional file}

Additional file 1: The file contains two tables showing modal compositions of samples (Table S1) and whole-rock compositions of samples (Table S2).

\section{Abbreviations}

Ab: albite; Act: actinolite; BPS: bleached pelitic schist; Cal: calcite; CAS: chlorite-actinolite schist; Chl: chlorite; CM: carbonaceous material; Ep: epidote; Ms: muscovite; Qtz: quartz; Ttn: titanite; UPS: unaltered pelitic schist.

\section{Competing interests}

The authors declare that they have no competing interests.

\section{Authors' contributions}

YM carried out the field investigation and sampling, performed the microscopic observation and analyses (Raman, XRF, CHN, and LOI), and drafted the manuscript. MS participated in the design of the study and helped in the field investigation, sampling, and CHN analysis. TN participated in the design of the study and helped in the field investigation and Raman analysis. All authors read and approved the final manuscript.

\section{Authors' information}

YM is a researcher/curator of petrology in Kitakyushu Museum of Natural History and Human History (KMNH). MS is a researcher of petrology/ structural geology in KMNH. TN is a professor of petrology in Graduate School of Science and Technology, Kumamoto University.

\section{Acknowledgements}

This study is financially supported by Grant-in-Aid for Young Scientists B (Nos. 16740303 and 21740385 to YM) from Japan Society for the Promotion of Science and by Grant-in-Aid for Scientific Research A (No. 17204045 to TN) and Grant-in-Aid for Scientific Research C (No. 24540524 to YM) from the Ministry of Education, Culture, Sports, Science and Technology, Japan. We appreciate reviews and comments by T. Morishita and anonymous reviewers.

\section{Author details}

${ }^{1}$ Kitakyushu Museum of Natural History and Human History, 2-4-1 Higashida, Yahatahigashi-ku, Kitakyushu 805-0071, Japan. ${ }^{2}$ Graduate School of Science and Technology, Kumamoto University, 2-39-1 Kurokami, Chuo-ku, Kumamoto 860-8555, Japan.

Received: 10 December 2013 Accepted: 16 April 2014

Published: 4 June 2014

\section{References}

Baumgartner LP, Olsen SN (1995) A least-squares approach to mass transport calculations using the isocon method. Econ Geol 90:1261-1270

Bebout GE (1996) Volatile transfer and recycling at convergent margins: mass-balance and insights from high-P/T metamorphic rocks. In: Bebout GE, Scholl DW, Kirby SH, Platt P (eds) Subduction top to bottom. American Geophysical Union, Geophysical Monograph series 96, Washington D.C, pp 179-193

Bebout GE (2007a) Metamorphic chemical geodynamics of subduction zones. Earth Planet Sci Lett 260:373-393

Bebout GE (2007b) Trace element and isotopic fluxes/subducted slab. Treat Geochem 3:1-50

Bebout GE (2013) Metasomatism in subduction zones of subducted oceanic slabs, mantle wedges, and the slab-mantle interface. In: Harlov DE, Austrheim $\mathrm{H}$ (eds) Metasomatism and the chemical transformation of rocks. Lecture notes in earth system science, Springer, Berlin, pp 289-349

Bebout GE, Barton MD (1989) Fluid flow and metasomatism in a subduction zone hydrothermal system: Catalina Schist terrane, California. Geology 17:976-980

Bebout GE, Barton MD (1993) Metasomatism during subduction: products and possible paths in the Catalina Schist, California. Chem Geol 108:61-92

Bebout GE, Barton MD (2002) Tectonic and metasomatic mixing in a high-T, subduction-zone mélange - insights into the geochemical evolution of the slab-mantle interface. Chem Geol 187:79-106

Breeding CM, Ague JJ, Bröcker M (2004) Fluid-metasedimentary interactions in subduction zone mélange: implications for the chemical composition of arc magmas. Geology 32:1041-1044

Davidson JP (1996) Deciphering mantle and crustal signature in subduction zone magmatism. In: Bebout GE, Scholl DW, Kirby SH, Platt P (eds) Subduction top to bottom. American Geophysical Union, Geophysical Monograph series 96, Washington D.C, pp 251-262

Elliott T (2003) Tracers of the slab. In: Eiler J (ed) Inside the subduction factory. American Geophysical Union, Geophysical Monograph series 138, Washington D.C, pp 23-45

Faure M, Fabbri O, Monie P (1988) The Miocene bending of southwest Japan: new ${ }^{39} \mathrm{Ar} /{ }^{40} \mathrm{Ar}$ and microtectonic constraints from the Nagasaki schists 
(western Kyushu), an extension of the Sanbagawa high-pressure belt. Earth Planet Sci Lett 91:105-116

Grant JA (1986) The isocon diagram - a simple solution to Gresens' equation for metasomatic alteration. Econ Geol 81:1976-1982

Hattori H, Shibata K (1982) Radiometric dating of pre-Neogene granitic and metamorphic rocks in northwest Kyushu, Japan - with emphasis on geotectonics of the Nishisonogi zone. Bull Geol Surv Japan 33:57-84

Hawkesworth CJ, Gallagher K, Hergt JM, McDermott F (1993) Mantle and slab contributions in arc magmas. Annu Rev Earth Planet Sci 21:175-204

King RL, Kohn MJ, Eiler JM (2003) Constraints on the petrologic structure of the subduction zone slab-mantle interface from Franciscan Complex exotic ultramafic blocks. Geol Soc Am Bull 115:1097-1109

King RL, Bebout GE, Moriguchi T, Nakamura E (2006) Elemental mixing systematics and Sr-Nd isotope geochemistry of mélange formation: obstacles to identification of fluid sources to arc volcanism. Earth Planet Sci Lett 246:288-304

King RL, Bebout GE, Grove M, Moriguchi T, Nakamura E (2007) Boron and lead isotope signatures of subduction-zone mélange formation: hybridization and fractionation along the slab-mantle interface beneath volcanic fronts. Chem Geol 239:305-322

Klemd R (2013) Metasomatism during high-pressure metamorphism: eclogites and blueschist-facies rocks. In: Harlov DE, Austrheim $\mathrm{H}$ (eds) Metasomatism and the chemical transformation of rocks. Lecture notes in earth system science, Springer, Berlin, pp 351-413

Manning CE (2004) The chemistry of subduction-zone fluids. Earth Planet Sci Lett 223:1-16

Marschall HR, Ludwig T, Altherr R, Kalt A, Tonarini S (2006) Syros metasomatic tourmaline: evidence for very high- $\delta{ }^{11} B$ fluids in subduction zones. J Petrol 47:1915-1942

Maury RC, Defant MJ, Joron JL (1992) Metasomatism of the sub-arc mantle inferred from trace elements in Philippine xenoliths. Nature 360:661-663

Miller DP, Marschall HR, Schumacher JC (2009) Metasomatic formation and petrology of blueschist-facies hybrid rocks from Syros (Greece): implications for reactions at the slab-mantle interface. Lithos 107:53-67

Mori Y, Mashima H (2005) X-ray fluorescence analysis of major and trace elements in silicate rocks using 1:5 dilution glass beads. Bull Kitakyushu Mus Nat His Hum Hist, Ser A 3:1-12

Mori Y, Nishiyama T, Yanagi T (2007) Chemical mass balance in a reaction zone between serpentinite and metapelites in the Nishisonogi metamorphic rocks, Kyushu, Japan: implications for devolatilization. Island Arc 16:28-39

Mori Y, Orihashi Y, Miyamoto T, Shimada K, Shigeno M, Nishiyama T (2011) Origin of zircon in jadeitite from the Nishisonogi metamorphic rocks, Kyushu, Japan. J Metamorphic Geol 29:673-684

Morris JD, Ryan JG (2003) Subduction zone processes and implications for changing composition of the upper and lower mantle. Treat Geochem 2:451-470

Morris JD, Leeman WP, Tera F (1990) The subducted component in island arc lavas: constraints from be isotopes B-Be systematics. Nature 344:31-36

Nishiyama T (1978) Jadeitite from the Nishisonogi metamorphic region. J Geol Soc Japan 84:155-156 (in Japanese)

Nishiyama T (1989) Petrologic study of the Nagasaki metamorphic rocks in the Nishisonogi peninsula - with special reference to the greenrock complex and the reaction-enhanced ductility. Mem Geol Soc Japan 33:237-257 (in Japanese with English abstract)

Nishiyama T (1990) $\mathrm{CO}_{2}$-metasomatism of a metabasite block in a serpentinite melange from the Nishisonogi metamorphic rocks, southwest Japan. Contrib Mineral Petrol 104:35-46

Peacock SM (1990) Fluid processes in subduction zones. Science 248:329-337

Penniston-Dorland SC, Sorensen SS, Ash RD, Khadke SV (2010) Lithium isotopes as a tracer of fluids in a subduction zone mélange: Franciscan Complex, CA. Earth Planet Sci Lett 292:181-190

Penniston-Dorland SC, Bebout GE, Pogge von Strandmann PAE, Elliott T (2012) Lithium and its isotopes as tracers of subduction zone fluids and metasomatic processes: evidence from the Catalina Schist, California, USA. Geochim Cosmochim Acta 77:530-545

Rüpke LH, Morgan JP, Hort M, Connolly JAD (2004) Serpentinite and the subduction zone water cycle. Earth Planet Sci Lett 223:17-34

Ryan J, Morris J, Bebout G, Leeman B (1996) Describing chemical fluxes in subduction zones: insights from "depth-profiling" studies of arc and forearc rocks. In: Bebout GE, Scholl DW, Kirby SH, Platt P (eds) Subduction top to bottom. American Geophysical Union, Geophysical Monograph series 96, Washington D.C, pp 263-268

Schmidt MW, Poli S (2003) Generation of mobile components during subduction of oceanic crust. Treat Geochem 3:567-591

Shigeno M, Mori Y, Nishiyama T (2005) Reaction microtextures in jadeitites from the Nishisonogi metamorphic rocks, Kyushu, Japan. J Mineral Petrol Sci 100:237-246

Shigeno M, Mori Y, Shimada K, Nishiyama T (2012a) Origin of omphacitites from the Nishisonogi metamorphic rocks, western Kyushu, Japan: comparison with jadeitites. Eur J Mineral 24:247-262

Shigeno M, Mori Y, Shimada K, Nishiyama T (2012b) Jadeitites with metasomatic zoning from the Nishisonogi metamorphic rocks, western Japan: fluid-tectonic block interaction during exhumation. Eur J Mineral 24:289-311

Sorensen SS, Grossman JN (1989) Enrichment of trace elements in garnet amphibolites from a paleo-subduction zone: Catalina Schist, southern California. Geochim Cosmochim Acta 53:3155-3177

Sorensen SS, Grossman JN (1993) Accessory minerals and subduction zone metasomatism: a geochemical comparison of two mélanges (Washington and California, U.S.A.). Chem Geol 110:269-297

Spandler C, Pirard C (2013) Element recycling from subducting slabs to arc crust: a review. Lithos 170-171:208-223

Spandler C, Hermann J, Faure K, Mavrogenes JA, Arculus RJ (2008) The importance of talc and chlorite "hybrid" rocks for volatile recycling through subduction zones; evidence from the high-pressure subduction mélange of New Caledonia. Contrib Mineral Petrol 155:181-198

Tatsumi Y, Eggins S (1995) Subduction zone magmatism. Blackwell Science, Oxford

Uchida Y, Muta K (1957) The talc deposits in northern Kyushu (1) - the distribution and types of talc deposits -. J Geol Soc Japan 63:586-597 (in Japanese with English abstract)

Uchida Y, Muta K (1958) The talc deposits in northern Kyushu (2) - on the talc deposits of the Nishisonogi type. J Geol Soc Japan 64:494-515 (in Japanese with English abstract)

doi:10.1186/1880-5981-66-47

Cite this article as: Mori et al:: Fluid-metapelite interaction in an ultramafic mélange: implications for mass transfer along the slab-mantle interface in subduction zones. Earth, Planets and Space $201466: 47$

\section{Submit your manuscript to a SpringerOpen ${ }^{\circ}$ journal and benefit from:}

- Convenient online submission

- Rigorous peer review

- Immediate publication on acceptance

- Open access: articles freely available online

- High visibility within the field

- Retaining the copyright to your article

Submit your next manuscript at $\gg$ springeropen.com 